\title{
Efficacy of Mediterranean Diet on Blood Biochemical Factors in Type II Diabetic Patients: A Randomized Controlled Trial
}

\author{
Tip II Diyabetik Hastalarda Akdeniz Diyetinin Kan Biyokimyasal Faktörleri Üzerindeki Etkinliği: Randomize Kontrollü \\ Bir Çalışma
}

\author{
Maryam Zahedi ${ }^{1,2}$, Seyed Amirreza Akhlagh ${ }^{3}$, Maryam Aboomardani ${ }^{1}$, Reza Alipoor ${ }^{4}$, Seyed Ahmad Hosseini ${ }^{5}$, Arash Rezaei \\ Shahmirzadi 6
}

${ }^{1}$ Clinical Research Development Unit, Sayyad Shirazi Hospital, Golestan University of Medical Sciences, Gorgan, Iran

${ }^{2}$ Gorgan congenital malformation research center, Golestan University of Medical Sciences, Gorgan, Iran

${ }^{3}$ Student Research Committee, Shiraz University of Medical Sciences, Shiraz, Iran

${ }^{4}$ Student Research Committee, Hormozgan University of Medical Sciences, Bandar Abbas, Iran

${ }^{5}$ Golestan University of Medical Sciences, Gorgan, Iran

${ }^{6}$ Student Research Committee, Golestan University of Medical Sciences, Gorgan, Iran

\section{ABSTRACT}

Introduction: Diabetes mellitus is one of the most common endocrinologic disorder and the seventh cause of mortality worldwide. In Mediterranean dietary, consumption of plant source food such as vegetables, fruits, seeds, beans etc. is much emphasized. There are many studies showed that this regimen can decrease the risk of cardiovascular disease and factors associated in diabetes mellitus. Therefore, in this study we investigated the efficacy of this regimen on blood biochemical factors in diabetic patients referred to diabetes clinic in Gorgan.

Methods: This was a clinical trial study in which 228 well-controlled type 2 diabetes mellitus patients between $40-60$ years were included in the study. They were randomly assigned to two different groups: control and Mediterranean educational intervention group. They followed up for 6 months and before and after the intervention, we evaluated the glycemic and lipid profile and physiological parameters in them. Data were analyzed by SPSS software.

Results: Totally 228 patients with diabetes mellitus type II between 40 to 60 years old were recruited. The mean age of patients was $57.3 \pm 9.28$ years old. Majority of participants were female (77.2\%) with elementary level of literacy (77.6\%). The mean of fasting blood glucose was $192.50 \pm 64.17 \mathrm{mg} / \mathrm{dL}$ in intervention group versus $208.48 \pm 87.90 \mathrm{mg} / \mathrm{dL}$ in control group $(P>0.05)$. This index was changed to $165.49 \pm 50.39 \mathrm{mg} / \mathrm{dL}$ in intervention group which was significantly lower than the amount in control group $(\mathrm{P}<0.001)$. A clinically and statistically significant fall in $\mathrm{HbA1c}$ was observed in intervention group rather than control group $(\mathrm{P}<0.001)$.

Conclusion: The present study represented a significant relationship between Mediterranean dietary intervention and both anthropometric and laboratory findings in patients with type 2 diabetes mellitus. We showed that this dietary could significantly lower the FBS, HbA1c, and LDL. Although we showed this meaningful difference, it should be more evaluated in Iranian race people to investigate more in this topic.

Key Words: Mediterranean dietary, type 2 diabetes mellitus, biochemical factors

\section{ÖZET}

Amaç: Diabetes mellitus, dünya çapında en yaygın endokrinolojik bozukluklardan biridir ve dünyada yedinci ölüm nedenidir. Akdeniz diyetinde sebze, meyve, tohum, fasulye vb. bitki kaynaklı besinlerin tüketimi çok vurgulanmaktadır. Bu rejimin kardiyovasküler hastalık riskini ve diabetes mellitus ile ilişkili faktörleri azaltabileceğini gösteren birçok çalışma var. Bu nedenle, bu çalışmada, Gorgan'daki diyabet kliniğine sevk edilen diyabetik hastalarda bu rejimin kan biyokimyasal faktörleri üzerindeki etkinliğini araştırdık.

Yöntem: Bu, 40-60 yaş arası 228 kontrollü tip 2 diabetes mellitus hastasının çalışmaya dahil edildiği bir klinik çalışma çalışmasıydı. Rastgele iki farklı gruba ayrıldılar: kontrol ve Akdeniz eğitim müdahale grubu. Müdahaleden önce ve sonra 6 ay takip ettiler, içlerindeki glisemik ve lipid profili ve fizyolojik parametreleri değerlendirdik. Veriler SPSS yazılımı ile analiz edildi.

Bulgular: 40 ila 60 yaşları arasında diabetes mellitus tip II olan toplam 228 hasta dahil edildi. Hastaların ortalama yaşı $57.3 \pm 9.28$ idi. Katılımcıların çoğunluğu kadındı $(\% 77,2)$ ve ilkokul okuryazarlığı $(\% 77,6)$ vardı. Açlık kan şekeri ortalaması müdahale grubunda $192.50 \pm 64.17 \mathrm{mg} / \mathrm{dL}$ iken kontrol grubunda $208.48 \pm$ $87.90 \mathrm{mg} / \mathrm{dL}$ idi ( $\mathrm{P}>0.05)$. Bu indeks müdahale grubunda $165.49 \pm 50.39 \mathrm{mg} /$ $\mathrm{dL}$ olarak değiştirildi ve kontrol grubundaki miktardan anlamlı derecede düşüktü $(P<0.001)$. HbA1c'de kontrol grubundan ziyade müdahale grubunda klinik ve istatistiksel olarak anlamlı düşüş gözlendi $(P<0.001)$.

Sonuç: Bu çalışma, tip 2 diabetes mellitus hastalarında Akdeniz beslenme müdahalesi ile hem antropometrik hem de laboratuvar bulguları arasında önemli bir ilişkiyi temsil etmektedir. Bu diyetin FBS, HbA1c ve LDL'yi önemli ölçüde düşürebileceğini gösterdik. Bu anlamlı farkı göstermiş olsak da bu konuda daha fazla araştırma yapabilmek için İran ırk insanlarında daha çok değerlendirilmelidir.

Anahtar Sözcükler: Akdeniz diyeti, tip 2 diabetes mellitus, biyokimyasal faktörler

Geliş Tarihi:04.01.2019

Kabul Tarihi: 05.10.2020

ORCID IDs: M.Z. 0000-0003-3410-4273, S.A.A. 0000-0003-1501-4539, R.A. 0000-0003-2107-8192, M.A. 0000-0002-8768-3064, S.A.H. 0000-0002-8404-0039, A.R.S. 00000002-5450-9588

Address for Correspondence / Yazışma Adresi: Dr. Arash Rezaei Shahmirzadi, Golestan University of Medical Sciences, Gorgan, Iran E-mail: ararshrezaie1372@protonmail.com

(CTelif Hakkı 2020 Gazi Üniversitesi Tıp Fakültesi - Makale metnine http://medicaljournal.gazi.edu.tr/ web adresinden ulaşılabilir. (c) Copyright 2020 by Gazi University Medical Faculty - Available on-line at web site http://medicaljournal.gazi.edu.tr/ 


\section{INTRODUCTION}

Diabetes mellitus type II is a chronic status that recognized by high glucose levels due to insulin resistance or decreased insulin secretion. It is in epidemic pattern worldwide and is going to increase even further in the future $(1,2)$ and is currently a major cause of morbidity and mortality in public health burden in the world (3). Over the past few years, there has been a great effort to study the relationship between dietary patterns and human health. Interestingly, adherence to a healthy life style was strongly associated with reduction in the risk of chronic illnesses with $83 \%$ reductionin coronary artery disease and $91 \%$ reduction in diabetes mellitus in females (4). The increasing incidence of diabetes worldwide has been highly linked to the westernized dietary patterns, physical inactivity, and increasing rates of obesity and metabolic syndrome (5).

Several studies have explored the efficacy of Mediterranean diet as one of the healthiest dietary patterns to protect chronic disease morbidity, higher life expectancy, and prevention of cardiovascular risks, Type 2 DM and non-alcoholic fatty liver (6). This pattern is distinguished by a high intake of legumes, nuts, cereals, fruits and vegetables, a higher intake of olive oil with less saturated fats intake, a higher consumption of fish compared with meat and poultry intake, low to moderate dairy products intake and moderate alcohol intake regularly (7). The beneficial roles of this dietary pattern are mainly attributed to its nutrient and non-nutrient compounds, including fibers, minerals, vitamins and phytochemicals (8). Nearly all of the studies concentrated on determining the relations between Mediterranean dietary pattern and risk of disease; consequently, Mediterranean dietary quality index (Med-DQI), which developed by Gerber et al for the first time, is a beneficial tool to assess dietary quality emphasis on two various sources of fat (olive oil and saturated) and two various sources of protein (meat and fish) with reverse scores (9).

There are some studies assessed the effect of Mediterranean diet on different clinical problems and had suitable outcomes (10-13). However, there are limited experimental evidences have been reported the effectiveness of diet in secondary prevention for diabetic patients (14). However, in recent years, there has been increased emphasis on investigating the role of diet in diabetes mellitus type II management and in systematic review with meta-analysis, the
Mediterranean diet was shown to be associated with better glycemic control and improved cardiovascular risk than control diets (2). Therefore, we in this study evaluated the efficacy of Mediterranean diet on blood biochemical factors in type II diabetic patients referred to diabetes clinic in Golestan Province, Northern Iran.

\section{METHODS}

This was a randomized paralleled clinical trial which is performed on 228 type II diabetic patients referred to Diabetes center of 5-Azar Hospital, Gorgan, Iran.

\section{Inclusion criteria}

Diabetes mellitus type II was confirmed if at least one or more of the following were reported: (a) HbAc1 $\geq 6.5 \%$, (b) fasting plasma glucose $\geq 126 \mathrm{mg} / \mathrm{dL}$ (7.0 $\mathrm{mmol} / \mathrm{L})$, (c) 2 -h plasma glucose $\geq 200 \mathrm{mg} / \mathrm{dL}(11.1 \mathrm{mmol} / \mathrm{L})$ during an oral glucose tolerance test, and (d) a random plasma glucose $\geq 200 \mathrm{mg} / \mathrm{dL}$ (11.1 $\mathrm{mmol} / \mathrm{L}$ ) in patients with symptoms of hyperglycemia. Patients were between 40 to 60 years old and were well-controlled under suitable treatment.

\section{Exclusion criteria}

We excluded patients with renal insufficiency, advanced liver and heart failure, severe physical disability, smoking and subjects who was under previous Mediterranean diet.

\section{Mediterranean diet intervention}

We randomized patients with fixed block randomization method. Patients were randomized into intervention and control groups and evaluated for 6 months (Figure1). We performed 8 education sections for patients in intervention group and they underwent classic Mediterranean diet in 25-person groups in two times (two-month gap between first and second intervention) by nutritionist. We followed them about observance of the dietary program and complementary education monthly.

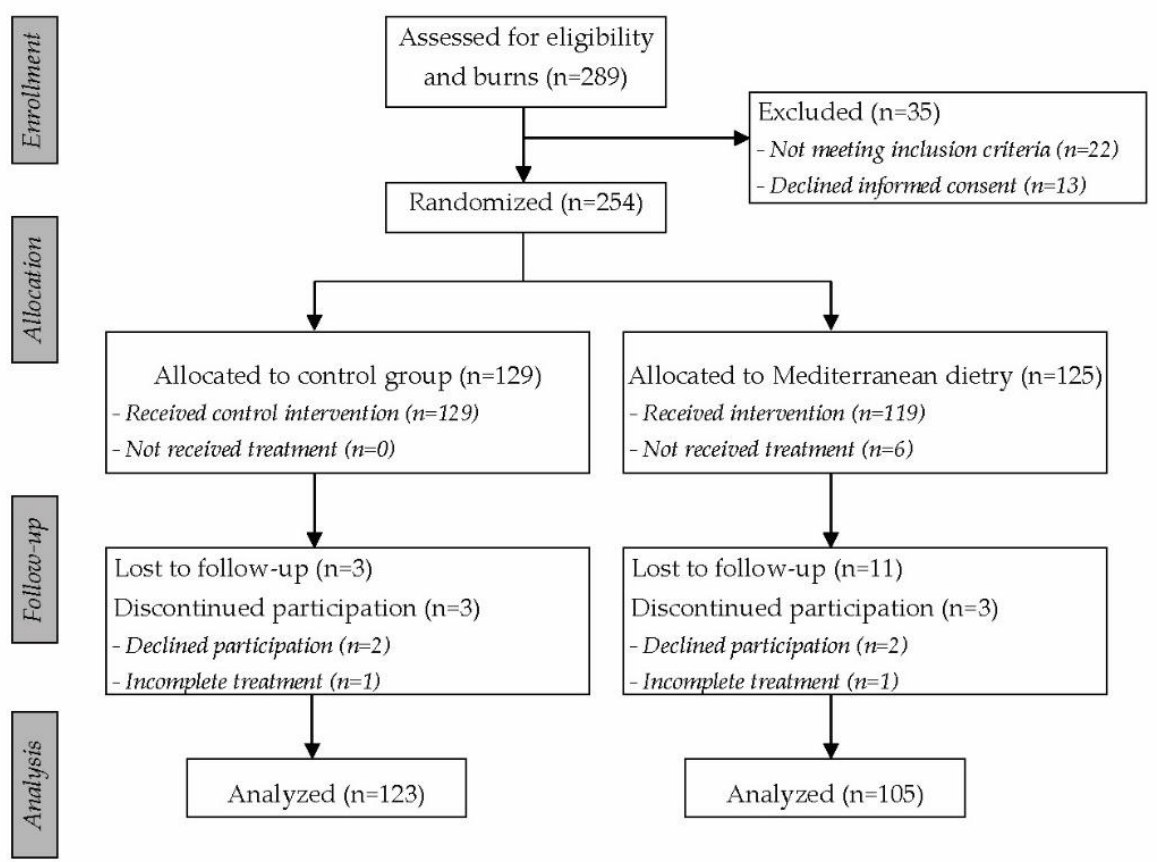

Figure1- Study Follow Chart

\section{Data collection and measurements}

Our main variables in this study were fasting blood sugar, lipid profile, body mass index (BMI) and type of treatment (routine vs routine+ Mediterranean diet). Patients underwent physical examination using standardized protocols in their visits and blood pressure measurements, laboratory tests and a dietary survey was recorded for them. BMI was calculated as weight $(\mathrm{kg}) /$ height $\left(\mathrm{m}^{2}\right) . \mathrm{HbA1c}$ was measured in EDTA treated whole blood using an automatic HPLC analyzer.
Plasma glucose, total cholesterol, HDL cholesterol (following precipitation of all plasma lipoproteins other than HDL, with $15 \%$ polyethyleneglycol, MW 6000) and triglyceride concentrations were analyzed on an automatic analyzer using commercial enzymatic kits. LDL cholesterol was calculated using the Friedewald formula (15). 
Sample size

The sample size was calculated with power $80 \%$ and based on Itsiopoulos et al. study (16) as 105 patients in each groups.

Statistics

All data were entered in SPSS (SPSS 21.0 for Windows; SPSS Inc. Chicago, Illinois). We used Independent T-Test for normal distribution quantitative data and nonparametric test (Mann Whitney Test) for other ones. Paired T-Test was used for comparison of two groups about intervention on glycemic and lipid profiles. Chi Square Test was used for comparison of qualitative variables. $P$ value lesser than 0.05 was considered as significant.

\section{Ethics}

This investigation was approved by ethical committee of Golsestan University of Medical Sciences with ethical code of IR.GOUMS.REC.1395.20 which was confirmed in May 2016. This study was registered in Iranian clinical trial registry with code of IRCT2017011131875N1in February 2017.

Information of participants was saved confidential without name and used only for research purpose. Patients were informed about the objectives of the study and written informed consent was obtained from them.

Table1- Demographics of participants in both intervention and control groups

\begin{tabular}{|c|c|c|c|c|c|}
\hline \multirow{2}{*}{ Variables } & & & \multicolumn{2}{|l|}{ Group } & \multirow{2}{*}{ P Value } \\
\hline & & & Control & Intervention & \\
\hline \multirow{2}{*}{ Age (years) } & \multirow{2}{*}{\multicolumn{2}{|c|}{$\begin{array}{l}\text { Mean } \\
\text { standard deviation }\end{array}$}} & 57.8 & 56.8 & \multirow{2}{*}{0.52} \\
\hline & & & 8.9 & 9.5 & \\
\hline \multirow{2}{*}{ Time from first diagnosis (years) } & \multirow{2}{*}{\multicolumn{2}{|c|}{$\begin{array}{l}\text { Mean } \\
\text { standard deviation }\end{array}$}} & 9.4 & 10.3 & \multirow{2}{*}{0.45} \\
\hline & & & 7.2 & 7.7 & \\
\hline \multirow{4}{*}{ Gender } & \multirow{2}{*}{ Male } & Frequency & 28 & 24 & \multirow{4}{*}{0.98} \\
\hline & & Percentage & 22.8 & 22.9 & \\
\hline & \multirow{2}{*}{ Female } & Frequency & 95 & 81 & \\
\hline & & Percentage & 77.2 & 77.2 & \\
\hline \multirow{2}{*}{ BMI $\left(\mathrm{Kg} / \mathrm{m}^{2}\right)$} & \multirow{2}{*}{\multicolumn{2}{|c|}{$\begin{array}{l}\text { Mean } \\
\text { standard deviation }\end{array}$}} & 31.21 & 30.14 & \multirow{2}{*}{0.43} \\
\hline & & & 2.49 & 3.21 & \\
\hline \multirow{6}{*}{ Literacy } & \multirow{2}{*}{ Illiterate } & Frequency & 54 & 30 & \multirow{6}{*}{0.06} \\
\hline & & Percentage & 45.8 & 34.1 & \\
\hline & \multirow{2}{*}{ High school } & Frequency & 54 & 39 & \\
\hline & & Percentage & 45.8 & 44.3 & \\
\hline & \multirow{2}{*}{ Graduate } & Frequency & 10 & 19 & \\
\hline & & Percentage & 8.4 & 21.6 & \\
\hline
\end{tabular}

\section{Laboratory and physiological outcomes}

The mean of fasting blood glucose was $192.50 \pm 64.17 \mathrm{mg} / \mathrm{dL}$ in intervention group versus $208.48 \pm 87.90 \mathrm{mg} / \mathrm{dL}$ in control group $(P>0.05)$. This index was changed to $165.49 \pm 50.39 \mathrm{mg} / \mathrm{dL}$ in intervention group which was significantly lower than the amount in control group $(P<0.001)$. Other laboratory and physiological findings of our patients are highlighted in Table2. There were no significant differences in plasma lipids (except LDL), systolic and diastolic pressure or blood 2-hours post prandial blood glucose (BS2HHP) ( $P>0.05)$.
They could exit the study in every stage of the clinical trial. We guaranteed to give the results to health policy makers of the province for every needed interventional or educational works.

\section{RESULTS}

Totally 228 patients with diabetes mellitus type II between 40 to 60 years old were recruited. Patients were randomized in two groups: intervention group ( $n=$ 105) and control group $(n=123)$.

The mean age of patients was $57.3 \pm 9.28$ years old. Majority of participants were female (77.2\%) with elementary level of literacy (77.6\%). Six subjects $(2.6 \%)$ were underweight, 33 of them (14.5\%) were in normal BMI, 121 of them (53.1\%) were overweight, 41 of them were obese $(18 \%)$ and other 27 participants $(11.8 \%)$ were very obese. The subjects had a mean $\mathrm{HbA} 1 \mathrm{c}$ of $8.7 \%(95 \% \mathrm{Cl}: 4.4-13.8)$ at recruitment and their mean duration of diabetes was 9.8 years $(95 \% \mathrm{Cl}: 1-36)$. There were no current smokers, however, 68 subjects (29.8\%) were former smokers. There was no report of consuming alcohol. Table1 shows demographic characteristics of participants in both groups.
A clinically and statistically significant fall in $\mathrm{HbA} 1 \mathrm{c}$ was observed in intervention group rather than control group $(\mathrm{P}<0.001)$. It showed that body mass index was not changed after 6-month intervention; however, it tended to decreased in intervention group which was not significant. Also, Table 2 demonstrated the comparison of pre and post intervention outcomes of laboratory and physiological outcomes. In intervention group all of indexes were developed significantly except TG $(P<0.05)$. In control group there was no significant difference at baseline and after 6 months except BS2HPP, DBP and HDL $(P<0.05)$. 
Table 2- Comparison of laboratory and physiological findings in two groups

\begin{tabular}{|c|c|c|c|c|c|c|}
\hline \multirow{2}{*}{ Variables } & & \multicolumn{2}{|l|}{ Control } & \multicolumn{2}{|l|}{ Intervention } & \multirow{2}{*}{ P-Value } \\
\hline & & Mean & standard deviation & Mean & standard deviation & \\
\hline & Before & 208.48 & 87.90 & 192.50 & 64.17 & 0.115 \\
\hline \multirow[t]{3}{*}{ Fasting blood glucose } & After & 199.88 & 71.83 & 165.49 & 50.39 & $<0.001$ \\
\hline & P-Value & 0.329 & & 0.001 & & - \\
\hline & Before & 8.76 & 1.70 & 8.75 & 1.53 & 0.96 \\
\hline \multirow[t]{2}{*}{ Hemoglobin A1c } & After & 8.81 & 1.51 & $7.84 \pm$ & 1.22 & $<0.001$ \\
\hline & P-Value & 0.726 & & 0.001 & & - \\
\hline \multirow{4}{*}{$\begin{array}{l}\text { Blood Sugar 2-hour Post } \\
\text { Prandial }\end{array}$} & Before & 295.78 & 10.2.27 & 273.16 & 79.99 & 0.068 \\
\hline & After & 237.24 & 68.94 & 225.25 & 66.61 & 0.184 \\
\hline & P-Value & 0.001 & & 0.001 & & - \\
\hline & Before & 174.66 & 99.40 & 169.68 & 68.15 & 0.656 \\
\hline \multirow[t]{3}{*}{ Triglyceride } & After & 159.06 & 53.49 & 164.08 & 57.30 & 0.497 \\
\hline & P-Value & 0.067 & & 0.454 & & - \\
\hline & Before & $161.47 \pm$ & 44.00 & $171.91 \pm$ & 47.50 & 0.089 \\
\hline \multirow[t]{3}{*}{$=$ Cholesterol total } & After & 153.35 & 27.01 & 158.34 & 22.28 & 0.128 \\
\hline & P-Value & 0.045 & & 0.004 & & - \\
\hline & Before & 92.68 & 30.56 & 102.47 & 37.65 & 0.340 \\
\hline \multirow[t]{3}{*}{ Low density lipoprotein } & After & 93.70 & 24.62 & 88.03 & 16.43 & 0.040 \\
\hline & P-Value & 0.721 & & 0.001 & & - \\
\hline & Before & 45.13 & 7.05 & $44.00 \pm 6.10$ & 6.10 & 0.102 \\
\hline \multirow[t]{3}{*}{ High density lipoprotein } & After & 43.01 & 8.66 & $41.20 \pm 7.94$ & 7.94 & 0.200 \\
\hline & P-Value & 0.006 & & 0.001 & & - \\
\hline & Before & 121.54 & 18.19 & 125.04 & 20.52 & 0.178 \\
\hline \multirow[t]{3}{*}{ systolic blood pressure } & After & 124.18 & & 114.37 & 11.92 & $<0.001$ \\
\hline & P-Value & 0.105 & & 0.001 & & - \\
\hline & Before & 76.60 & 9.05 & 80.55 & 26.25 & 0.144 \\
\hline \multirow[t]{3}{*}{ diastolic blood pressure } & After & 74.24 & 7.29 & 72.29 & 6.92 & 0.040 \\
\hline & P-Value & 0.009 & & 0.002 & & - \\
\hline & Before & 28.44 & 4.54 & 29.48 & 5.22 & 0.116 \\
\hline \multirow[t]{2}{*}{ body mass index } & After & 28.52 & 4.47 & 28.36 & 4.22 & 0.780 \\
\hline & P-Value & 0.250 & & 0.001 & & - \\
\hline
\end{tabular}

\section{DISCUSSION}

In this study we investigated the efficacy of this regimen on blood biochemical factors in diabetic patients referred to diabetes clinic in Gorgan. The mean of fasting blood glucose was $192.50 \pm 64.17 \mathrm{mg} / \mathrm{dL}$ in intervention group versus $208.48 \pm 87.90 \mathrm{mg} / \mathrm{dL}$ in control group. This index was changed to $165.49 \pm 50.39$ $\mathrm{mg} / \mathrm{dL}$ in intervention group which was significantly lower than the amount in control group. A clinically and statistically significant fall in $\mathrm{HbA1c}$ was observed in intervention group rather than control group.

Traditionally, dietary recommendations have targeted macronutrient levels. However, recent dietary guidelines (17) have shifted towards a more food-based dietary pattern approach. Although several macronutrients, micronutrients and individual foods have been associated with diabetes risk, assessment of dietary patterns is increasingly used as an alternative method to traditional single nutrient analysis because it can assess cumulative effects of the overall diet (18). Our purpose was to assess the efficacy of Mediterranean diet on blood biochemical factors in type II diabetic patients referred to diabetes clinic in Golestan Province, Northern Iran.

Current evidence indicates that the Mediterranean diet is effective in improving both glycemic control and cardiovascular risk factors in people with type 2 diabetes, and should therefore be considered in the overall strategy for management of people with diabetes. The convergence analysis of prospective studies and interventional trials was satisfied: The Mediterranean diet is able to reduce the incidence of future diabetes by $19-23 \%$. A significant reduction of type 2 diabetes has been found to be associated with greater consumption of healthy dietary patterns, including the Mediterranean diet, the DASH (Dietary Approach to Stop Hypertension) diet, the AHEI (Alternative Healthy Eating Index) and various a posteriori defined prudent/healthy dietary patterns, derived by factor or cluster analysis (19). We showed that Mediterranean diet intervention can improve glycemic and lipid profile in type 2 diabetes mellitus patients except TG in before-after analysis after 6-month intervention. Also in comparison with control group, in FBS and $\mathrm{HbA1c}$ and LDL in laboratory findings we showed that there were significant differences. In blood pressure also we showed that in comparison with control group it was decreased meaningful after intervention.
In the PREDIMED study, both Mediterranean diet groups showed improvements in dyslipidemia compared with the low fat group (20) but we could not assess this in our study. A recent study found that a Mediterranean diet in newly diagnosed type 2 diabetes, was associated with a delayed need for anti-hyperglycemic drugs (21), and we have reported that in people with type 2 diabetes, a Mediterranean diet consumed, reduced $\mathrm{HbA} 1 \mathrm{c}$ from $8.75 \%$ to $7.84 \%$. It is reported in another study that by using this diet, $\mathrm{HbA} 1 \mathrm{c}$ reduced from $7.1 \%$ to $6.8 \%$ (16). Esposito el al. showed that in Type 2 diabetes, greater adherence to a Mediterranean type diet is associated with lower $\mathrm{HbA} 1 \mathrm{c}$ and postprandial glucose levels. Mean $\mathrm{HbA} 1 \mathrm{c}$ and $2 \mathrm{~h}$ post-meal glucose concentrations were significantly lower in diabetic patients with high adherence to a Mediterranean type diet than those with low adherence (21). The Mediterranean diet includes foods that are recommended separately for medical nutrition therapy for diabetes, and is associated with reduced total and cardiovascular mortality. There is a good case for recommending a Mediterranean style diet for all, including people with type 2 diabetes (22). Previous studies of people with type 2 diabetes have shown benefits of replacing saturated fat with monounsaturated fatty acid (MUFA) which is enriched in Mediterranean diet; a 1998 meta-analysis of 10 randomized cross-over trials showed that a MUFA rich diet improved lipid profiles, glycemic control, when compared with a high carbohydrate diet, when energy intake was controlled (23). Barona et al. was able to show that Mediterranean-style low-glycemic-load diet for 12 weeks in thirty-five women with metabolic syndrome and high LDL levels (>100 mg/dl) significantly reduced oxidized LDL (12\% in Mediterranean diet) (24).

Estruch et al.(20) showed that compared with the low fat diet, the mean changes in the Mediterranean diet with olive oil group nd the Mediterranean diet with nuts group were $0.39 \mathrm{mmol} / \mathrm{L}(95 \% \mathrm{Cl}, 0.70$ to $0.07 \mathrm{mmol} / \mathrm{L})$ and 0.30 $\mathrm{mmol} / \mathrm{L}(\mathrm{Cl}, 0.58$ to $0.01 \mathrm{mmol} / \mathrm{L})$, respectively, for plasma glucose levels; $5.9 \mathrm{~mm}$ $\mathrm{Hg}(\mathrm{Cl}, 8.7$ to $3.1 \mathrm{~mm} \mathrm{Hg})$ and $7.1 \mathrm{~mm} \mathrm{Hg}(\mathrm{Cl}, 10.0$ to $4.1 \mathrm{~mm} \mathrm{Hg})$, respectively, for systolic blood pressure; and $0.38(\mathrm{Cl}, 0.55$ to 0.22$)$ and $0.26(\mathrm{Cl}, 0.42$ to 0.10$)$, respectively, for the cholesterol high density lipoprotein cholesterol ratio. 
Shai et al. evaluated the Low-fat restricted calorie diet versus Mediterranean calorie-restricted diet versus low carbohydrate non-restricted calorie diet and demonstrated that fasting glucose decreased in Mediterranean arm (by -32.8 $\mathrm{mg} / \mathrm{dl}$ in the Mediterranean diet compared to baseline and increased by 12.1 $\mathrm{mg} / \mathrm{dl}$ in low-fat diet; P value 0.001) and there was no change in HbA1c (25). There were controversial outcomes in different studies. We showed that similar to majority of studies that this diet can significantly develop the glycemic and lipid profile control in type 2 diabetes mellitus rather than control group.

\section{CONCLUSION}

The present study represented a significant relationship between Mediterranean dietary intervention and both anthropometric and laboratory findings in patients with type 2 diabetes mellitus. We showed that this dietary can significantly lower the FBS and HbA1c and LDL. Although we showed this meaningful difference, it should be more evaluated in Iranian race people to investigate more in this topic. One of our limitation was moderately low study population, short time of follow up, lack of investigation in some indexes. It remains for future research to determine the replicability of the intervention, especially with more diverse populations, and its cost-effectiveness relative to other programs. The antioxidant characteristic of Mediterranean dietary rich content of fruits, vegetables and cereals seems to play a major role in its protective potential in diabetes mellitus beside dietary fiber which is believed to induce satiety and thus reduce caloric intake.

\section{Conflict of interest}

No conflict of interest was declared by the authors.

\section{Acknowledgements}

We thank all of personnel in diabetes clinic of Gorgan for their cooperation. We also thank the moral support of Clinical Research Development Unit (CRDU) in 5Azar Hospital in the performance of our work. Also we thank Fatemeh Mehravar, Soheila Samadzadeh and Fatemeh Maghsoudloo that helped all colleagues in this project.

\section{REFERENCES}

1. Rani V, Deep G, Singh RK, Palle K, Yadav UC. Oxidative stress and metabolic disorders: pathogenesis and therapeutic strategies. Life sciences. 2016;148:18393.

2. Esposito K, Maiorino MI, Bellastella G, Chiodini P, Panagiotakos D, Giugliano D. A journey into a Mediterranean diet and type 2 diabetes: a systematic review with meta-analyses. BMJ open. 2015;5(8):e008222.

3. Organization WH. Global report on diabetes: World Health Organization; 2016.

4. Rimm EB, Stampfer MJ. Diet, lifestyle, and longevity-the next steps? Jama. 2004;292(12):1490-2.

5. Sleiman D, Al-Badri MR, Azar ST. Effect of Mediterranean diet in diabetes control and cardiovascular risk modification: a systematic review. Frontiers in public health. 2015;3:69.

6. Mohseni F, Farhangi MA, Farajnia S, Khoshbaten M, Ajourlou E, Kakaei F. Adherence to Mediterranean nutrition pattern in patients with non-alcoholic fatty liver disease: Relationship with metabolic risk factors and-UCP2-866G/a gene polymorphisms. Current Topics in Nutraceuticals Research. 2016;14(1):49.

7. Tur JA, Romaguera D, Pons A. The Diet Quality Index-International (DQII): is it a useful tool to evaluate the quality of the Mediterranean diet? British journal of nutrition. 2005;93(03):369-76.

8. Georgoulis M, Kontogianni M, Margariti A, Tiniakos D, Fragopoulou E, Zafiropoulou R, et al. Associations between dietary intake and the presence of the metabolic syndrome in patients with non-alcoholic fatty liver disease. Journal of Human Nutrition and Dietetics. 2015;28(4):409-15

9. Gerber M. The comprehensive approach to diet: a critical review. The Journal of nutrition. 2001;131(11):3051S-5S.

10. Martínez-González MÁ, Sánchez-Villegas A. Review: The emerging role of Mediterranean diets in cardiovascular epidemiology: Monounsaturated fats, olive oil, red wine or the whole pattern? European journal of epidemiology. 2004;19(1):9-13.

11. Estruch R, Martínez-González MA, Corella D, Salas-Salvadó J, RuizGutiérrez V, Covas $\mathrm{Ml}$, et al. Effects of a mediterranean-style diet on cardiovascular risk factorsa randomized trial. Annals of internal medicine. 2006;145(1):1-11.
12. Trichopoulou A, Costacou T, Bamia C, Trichopoulos D. Adherence to a Mediterranean diet and survival in a Greek population. New England Journal of Medicine. 2003;348(26):2599-608.

13. Esposito K, Marfella R, Ciotola M, Di Palo C, Giugliano F, Giugliano G, et al. Effect of a Mediterranean-style diet on endothelial dysfunction and markers of vascular inflammation in the metabolic syndrome: a randomized trial. Jama. 2004;292(12):1440-6.

14. Psaltopoulou T, llias I, Alevizaki M. The role of diet and lifestyle in primary, secondary, and tertiary diabetes prevention: a review of meta-analyses. Rev Diabet Stud. 2010;7(1):26-35.

15. Friedewald WT, Levy RI, Fredrickson DS. Estimation of the concentration of low-density lipoprotein cholesterol in plasma, without use of the preparative ultracentrifuge. Clinical chemistry. 1972;18(6):499-502.

16. Itsiopoulos C, Brazionis L, Kaimakamis M, Cameron M, Best JD, O'Dea K, et al. Can the Mediterranean diet lower HbA1c in type 2 diabetes? Results from a randomized cross-over study. Nutrition, Metabolism and Cardiovascular Diseases. 2011;21(9):740-7.

17. Committee DGA. Scientific report of the 2015 dietary guidelines advisory committee. Washington (DC): USDA and US Department of Health and Human Services. 2015.

18. Ley SH, Hamdy O, Mohan V, Hu FB. Prevention and management of type 2 diabetes: dietary components and nutritional strategies. The Lancet. 2014;383(9933):1999-2007.

19. Esposito K, Chiodini P, Maiorino MI, Bellastella G, Panagiotakos D, Giugliano D. Which diet for prevention of type 2 diabetes? A meta-analysis of prospective studies. Springer; 2014.

20. Estruch R, Martínez-González MA, Corella D, Salas-Salvadó J, RuizGutiérrez V, Covas MI, et al. Effects of a Mediterranean-Style Diet on Cardiovascular Risk FactorsA Randomized TrialMediterranean Diet and Cardiovascular Risk Factors. Annals of internal medicine. 2006;145(1):1-11.

21. Esposito K, Maiorino MI, Ciotola M, Di Palo C, Scognamiglio P, Gicchino M, et al. Effects of a Mediterranean-Style Diet on the Need for Antihyperglycemic Drug Therapy in Patients With Newly Diagnosed Type 2 DiabetesA Randomized Trial. Annals of internal medicine. 2009;151(5):306-14.

22. Hodge A, English D, Itsiopoulos C, O'Dea K, Giles G. Does a Mediterranean diet reduce the mortality risk associated with diabetes: evidence from the Melbourne Collaborative Cohort Study. Nutrition, Metabolism and Cardiovascular Diseases. 2011;21(9):733-9.

23. Garg A. High-monounsaturated-fat diets for patients with diabetes mellitus: a meta-analysis. The American journal of clinical nutrition. 1998;67(3):577S-82S.

24. Barona J, Jones JJ, Kopec RE, Comperatore M, Andersen C, Schwartz SJ, et al. A Mediterranean-style low-glycemic-load diet increases plasma carotenoids and decreases LDL oxidation in women with metabolic syndrome. The Journal of nutritional biochemistry. 2012;23(6):609-15.

25. Shai I, Schwarzfuchs D, Henkin Y, Shahar DR, Witkow S, Greenberg I, et al. Weight loss with a low-carbohydrate, Mediterranean, or low-fat diet. N Engl J Med. 2008;2008(359):229-41. 